\title{
GROWTH AND METABOLISM OF PREIMPLANTATION MOUSE EMBRYOS CULTURED IN PHOSPHATE- BUFFERED MEDIUM
}

\author{
P. QUINN* AND R. G. WALES \\ Department of Veterinary Physiology, University of Sydney, \\ Sydney, 2006, Australia
}

(Received 10th October 1972)

\begin{abstract}
Summary. The development of two-cell, eight-cell and morula stages of the mouse embryo in phosphate-buffered medium incubated aerobically was limited to that which occurred during the initial $24 \mathrm{hr}$ of culture. Fewer embryos developed in phosphate- than in bicarbonatebuffered medium. More two-cell embryos developed in $4 \mathrm{~mm}$ - than in $1 \mathrm{~mm}$-phosphate-buffered medium but there was no difference in the number of eight-cell embryos and morulae developing in either concentration. Addition of oxaloacetate or malate to phosphate-buffered media did not improve development. With incubation periods of 2 to $12 \mathrm{hr}$, two-cell embryos were more susceptible to phosphate than eightcell embryos.
\end{abstract}

Culture for $24 \mathrm{hr}$ in phosphate-buffered medium resulted in a reduced incorporation of pyruvate and lactate carbon into the acidsoluble fraction of embryos at all stages of development. In embryos cultured from the two-cell and eight-cell stage, incorporation of substrate carbon into protein and, to a lesser extent, RNA and DNA was also depressed after culture in phosphate-buffered medium. This reduced synthetic activity could result in less ATP utilization and may be responsible in part for the higher levels of ATP found in embryos at these stages after culture in phosphate- as compared to bicarbonatebuffered medium. At the morula stage, macromolecular synthesis was not affected by culture in phosphate-buffered medium and the ATP levels in these embryos were similar to those in embryos developing in bicarbonate-buffered medium. The oxidation of pyruvate by embryos also indicated that the utilization rather than the production of ATP was more affected by culture in phosphate- than in bicarbonatebuffered medium.

\section{INTRODUCTION}

There are few references in the literature to the effects of non-carboxylic buffering compounds on the development of mammalian embryos in vitro.

* Present address: The Jackson Laboratory, Bar Harbor, Maine 04609, U.S.A. 
Thomson (1969) tested a range of these compounds, including tris and phosphate, and found that the development of two-cell mouse embryos continued over a few cleavages only. Whitten (1971) also reported little success with these compounds although a large portion, but not all, of the bicarbonate in culture medium could be replaced by hepes buffer. Phosphate-buffered media have been used in short-term studies with mouse embryos and have been found to have no deleterious effect on the subsequent development of the embryos in bicarbonate-buffered medium (Mills \& Brinster, 1967; Whittingham \& Wales, 1969).

Since the fixation of $\mathrm{CO}_{2}$ is an important process in the metabolism of mouse embryos (Graves \& Biggers, 1970; Quinn \& Wales, 1971), it is to be expected that the absence of $\mathrm{CO}_{2}$ may be deleterious to the embryo. This has been shown with other tissues and various substrates, such as oxaloacetate and citrate, have been included in the medium to compensate for the lack of $\mathrm{CO}_{2}$ (see Paul, 1965).

The present study was undertaken to investigate the effects of phosphatebuffered media on mouse embryos at various stages of development. The growth and metabolism of embryos during culture in phosphate-buffered medium have been compared to those in bicarbonate-buffered medium. The metabolism of the embryos was assessed by measuring the oxidative turnover of pyruvate, the incorporation of substrate carbon from pyruvate and lactate and the levels of ATP in the embryos. Since the activity of NADP-malate dehydrogenase (E.C. 1.1.1.40), the enzyme most concerned with the fixation of $\mathrm{CO}_{2}$ in mouse embryos, increases as development progresses (Quinn \& Wales, 1971), the activity of this enzyme was measured in cultured embryos to determine if the changes in its activity were dependent upon the presence of $\mathrm{CO}_{2}$.

\section{MATERIALS AND METHODS}

\section{General}

Embryos from the two-cell to late blastocyst stages were flushed from the reproductive tracts of randomly bred albino mice induced to superovulate at 48 to $120 \mathrm{hr}$ after the injection of HCG (Brinster, 1965a). The basic medium used for collection of embryos was a modified Krebs-Ringer bicarbonate solution described by Brinster (1965b) and it contained 25 mM-DL-sodium lactate and $0.25 \mathrm{~mm}$-sodium pyruvate as energy sources for the embryos.

Embryos were cultured in droplets of medium under paraffin oil in plastic culture dishes at $37^{\circ} \mathrm{C}$ (Brinster, 1963). To determine the effects of phosphatebuffered medium on development, embryos were cultured in $1 \mathrm{~mm}$ - and $4 \mathrm{~mm}$ phosphate-buffered media ( $\mathrm{pH} \mathrm{7.4)}$ and their development compared with that of embryos cultured in basic medium. The phosphate-buffered media were similar in all respects to the basic medium except that phosphate buffer (stock of 0.1 M- $\mathrm{Na}_{2} \mathrm{HPO}_{4}$ adjusted to $\mathrm{pH} 7.4$ with 1 N-HCl-Umbreit, Burris \& Stauffer, 1959) replaced bicarbonate buffer and isotonicity was maintained by adjusting the sodium chloride content. Embryos for culture were washed in two changes ( $2 \mathrm{ml} /$ wash) of the appropriate culture medium before transfer to the culture dishes. Bicarbonate-buffered medium was incubated 
under an atmosphere of $5 \% \mathrm{CO}_{2}: 95 \%$ air, while phosphate-buffered media were incubated in an atmosphere of air.

As oxaloacetate and malate have been found to be intermediates in the fixation of $\mathrm{CO}_{2}$ in the mouse embryo (see Quinn \& Wales, 1971), the effects of their addition to the phosphate-buffered media on the development of the embryos were tested. Solutions of oxaloacetic and malic acids were neutralized and added to the media at a concentration of $0.25 \mathrm{~mm}$. At the two-cell stage, only the addition of oxaloacetate to the phosphate-buffered media was tested since the uptake of malate has been shown to be low at this stage (Wales \& Biggers, 1968). In addition, pyruvate carboxylase (E.C. 6.4.1.1), the enzyme which synthesizes oxaloacetate from pyruvate and $\mathrm{CO}_{2}$ is the major enzyme responsible for the fixation of $\mathrm{CO}_{2}$ in the early stages of development of the mouse embryo (Quinn \& Wales, 1971).

In the experiments where radioactive compounds were used, all samples were radioassayed by liquid scintillation techniques using $5 \mathrm{ml}$ Triton X100toluene $(1: 2 \mathrm{v} / \mathrm{v})$ containing $0.4 \%(\mathrm{w} / \mathrm{v}) 2,5$-diphenyloxazole and $0.01 \%$ (w/v) 1,4-bis(4-methyl-5-phenyloxazol-2-yl)benzene for each $0.4 \mathrm{ml}$ of aqueous sample. All radioactive substrates were obtained from Amersham Laboratories.

\section{Production of carbon dioxide}

The method used for measuring the production of $\mathrm{CO}_{2}$ by embryos was based on the technique described by Brinster (1967). Between 130 and 180 two-cell embryos and 40 to 80 morulae were cultured for $21 \mathrm{hr}$ in either $4 \mathrm{~mm}$-phosphatebuffered or $25 \mathrm{~mm}$-bicarbonate-buffered medium. The embryos which had developed during this period were collected, washed twice $(2 \mathrm{ml} /$ wash $)$ in substrate-free medium and incubated in sealed vials for $3 \mathrm{hr}$ at $37^{\circ} \mathrm{C}$ in $50 \mu \mathrm{l}$ medium containing $0.5 \mathrm{~mm}-\left[2-{ }^{14} \mathrm{C}\right]$ sodium pyruvate $(6.8 \mu \mathrm{Ci} / \mu \mathrm{mol})$. Both the washing and radioactive media contained the same buffering system as that in which the embryos had been cultured for $21 \mathrm{hr}$ previously. As controls, 70 to 120 eight-cell embryos and 20 to 30 late blastocysts which had been freshly collected were also washed in substrate-free medium and incubated for $3 \mathrm{hr}$ in bicarbonate-buffered medium containing $\left[2-{ }^{14} \mathrm{C}\right]$ pyruvate.

At the end of the 3-hr incubation period, the radioactive $\mathrm{CO}_{2}$ evolved by the embryos was liberated from the medium by acidification, absorbed in sodium hydroxide and submitted to radioassay (Wales \& Whittingham, 1967).

\section{Incorporation of pyruvate and lactate carbon}

Two-cell, eight-cell and morulae stages of embryos were cultured for $24 \mathrm{hr}$ in either $4 \mathrm{~mm}$-phosphate-buffered or $25 \mathrm{~mm}$-bicarbonate-buffered medium. Between 140 and 700 embryos, depending on the stage of development which had taken place during the 24-hr culture, were collected from the culture media, washed twice in bicarbonate-buffered substrate-free medium and transferred to bicarbonate-buffered medium containing $\left[2-{ }^{14} \mathrm{C}\right]$ sodium pyruvate $(0.5 \mathrm{~mm})$ and $\left[2-{ }^{14} \mathrm{C}\right]$ DL-sodium lactate $(5 \mathrm{~mm})$, both at a specific activity of $2.48 \mu \mathrm{Ci} / \mu \mathrm{mol}$. After a $2-\mathrm{hr}$ incubation period, ten embryos were removed from the medium and collected by centrifugation (Wales \& Biggers, 1968; Wales \& 
Whittingham, 1970). The total uptake of radioactive substrate in these embryos was assessed by liquid scintillation counting. The remaining embryos were collected in a similar manner and the accumulated radioactivity fractionated into acid-soluble, glycogen, RNA, DNA and protein portions by the method of Shibko, Koivistoinen, Tratnyek, Newhall \& Friedman (1967) as modified by I. L. Pike (personal communication) for small amounts of tissue. The lipid material was extracted from the protein fraction with chloroform-ether mixtures (Wales \& Whittingham, 1970).

\section{Adenosine triphosphate assays}

Between thirty and sixty embryos from the two-cell to morula stage were cultured for $24 \mathrm{hr}$ in media buffered with either $4 \mathrm{~mm}$-phosphate or $25 \mathrm{~mm}$ bicarbonate. At the end of the culture period, the embryos which had developed were collected and extracted with $50 \mu \mathrm{l}$ ice-cold $2.5 \%$ perchloric acid for $\frac{1}{2}$ to $1 \mathrm{hr}$. The ATP in these extracts was assayed by the firefly luciferase method as described previously (Quinn \& Wales, 1973). The levels of ATP in forty to sixty freshly collected eight-cell embryos, morulae and late blastocysts were assayed in a similar fashion.

\section{Statistical analysis}

Data of the percentage of embryos developing in the various media were transformed to angles before analysis, whereas the data obtained from the experiments on the production of $\mathrm{CO}_{2}$ and the incorporation of energy substrates into the embryos were transformed to logarithms. The significance of the results was assessed by standard analysis of variance.

\section{RESULTS}

\section{Development in phosphate-buffered media}

To determine the development of embryos in non-carboxylic buffers, twocell, eight-cell and morula stages were cultured in media buffered by hepes, tes and tris at concentrations of $25 \mathrm{~mm}$ as well as in media buffered by 1,4 and 16 mm-phosphate. The growth of embryos in media buffered by hepes, tes and tris was very poor and only an occasional embryo cleaved once or twice. In 16 mM-phosphate-buffered medium, a precipitate formed on the embryos after several hours of culture. At all stages, some of the embryos developed in 1 and 4 mм-phosphate-buffered medium but the development was limited to that which occurred during the initial $24 \mathrm{hr}$ of culture.

Two-cell mouse embryos were cultured in 1 and $4 \mathrm{~mm}$-phosphate-buffered medium under an atmosphere of air with and without the addition of oxaloacetate to the media. The proportion of these embryos developing to the four to eight-cell stage as compared to those cultured in bicarbonate-buffered medium is given in Table 1. More embryos developed in the bicarbonate-buffered medium than in any of the phosphate-buffered media $(P<0.01)$. Medium containing 4 ms-phosphate supported the development of more two-cell embryos than medium buffered with $1 \mathrm{~mm}$-phosphate $(P<0 \cdot 01)$ but the addition of oxaloacetate had no effect on the number of embryos developing. 
The development of eight-cell and morula stages during 24-hr culture in phosphate-buffered medium with and without the addition of oxaloacetate and malate is also given in Table 1. As with two-cell embryos, fewer embryos developed in the phosphate-buffered media than in the control bicarbonatebuffered medium $(P<0.01)$ but there was no significant difference in the proportion of embryos developing at either concentration of phosphate. Although fewer $(P<0.05)$ eight-cell embryos developed in the phosphate-buffered media which had been supplemented with either oxaloacetate or malate, these treatments had no significant effect on the number of embryos developing from the morula stage. Preliminary experiments had shown that the addition of oxalo-

Table 1. Effect of buffering system on the development of mouse embryos during culture for $24 \mathrm{hr}$ in medium containing $25 \mathrm{~mm}$-lactate and $0.5 \mathrm{~mm}$ pyruvate with and without the addition of oxaloacetate or malate

\begin{tabular}{|c|c|c|c|c|c|}
\hline \multirow[b]{2}{*}{$\begin{array}{l}\text { Buffering } \\
\text { system }\end{array}$} & \multicolumn{2}{|c|}{ Additional substrate } & \multicolumn{3}{|c|}{$\%$ embryos developed } \\
\hline & $\begin{array}{c}\text { Oxaloacetate } \\
(0.25 \mathrm{mM})\end{array}$ & $\begin{array}{c}\text { Malate } \\
(0.25 \mathrm{mM})\end{array}$ & $\begin{array}{c}\text { 2-cell to } \\
4-/ 8 \text {-cell }\end{array}$ & $\begin{array}{l}\text { 8-cell to } \\
\text { morula } \dagger\end{array}$ & $\begin{array}{c}\text { Morula to } \\
\text { blastocyst }\end{array}$ \\
\hline 4 mM-phosphate & $\overline{+}$ & $\overline{-}$ & $\begin{array}{r}87 \pm 12 \\
85 \pm 6 \\
-6\end{array}$ & $\begin{array}{l}75 \pm 7 \\
66 \pm 5 \\
73 \pm 6\end{array}$ & $\begin{array}{l}67 \pm 8 \\
60 \pm 8 \\
70 \pm 9\end{array}$ \\
\hline $1 \mathrm{~mm}$-phosphate & $\bar{t}$ & $\overline{-}$ & $\begin{array}{c}55 \pm 15 \\
58 \pm 10 \\
-\end{array}$ & $\begin{array}{l}78 \pm 5 \\
54 \pm 8 \\
60 \pm 9\end{array}$ & $\begin{array}{l}67 \pm 8 \\
78 \pm 3 \\
57 \pm 12\end{array}$ \\
\hline $25 \mathrm{~mm}$-bicarbonate & - & - & $97 \pm 2$ & $95 \pm 3$ & $88 \pm 4$ \\
\hline
\end{tabular}

Mean values \pm S.E. of the means are given.

* Total of sixty embryos/treatment (six replicates, ten embryos/treatment).

† Total of eighty embryos/treatment (eight replicates, ten embryos/treatment).

\$ Total of sixty embryos/treatment (six replicates, ten embryos/treatment).

acetate or malate to bicarbonate-buffered medium did not alter the proportion of embryos developing.

Since two- and eight-cell embryos showed no further development beyond that which occurred during the first $24 \mathrm{hr}$ of culture in phosphate-buffered medium, their continued development in bicarbonate-buffered medium subsequent to incubation for 2 to $12 \mathrm{hr}$ in phosphate-buffered medium was tested. Equal numbers of embryos were incubated in six droplets of $4 \mathrm{~mm}$-phosphatebuffered medium. At 2-hr intervals, the embryos from one drop of medium were transferred to bicarbonate-buffered medium and their development to the blastocyst stage was recorded (Table 2). After $72 \mathrm{hr}, 60 \%$ of the two-cell embryos which were cultured in bicarbonate medium immediately after collection had developed to the blastocyst stage. When the two-cell embryos were initially incubated in phosphate-buffered medium, fewer embryos than those cultured for the whole period in bicarbonate-buffered medium subsequently developed to the blastocyst stage after being transferred to bicarbonatebuffered medium. As the length of prior incubation in phosphate-buffered medium increased, the number of two-cell embryos which developed declined gradually so that the proportion of blastocysts developing from two-cell embryos 
which had been incubated for $12 \mathrm{hr}$ in phosphate-buffered medium was only $36 \%$.

Eight-cell embryos were less susceptible to the effects of incubation in $4 \mathrm{~mm}$ phosphate-buffered medium than two-cell embryos. Only after incubation for $10 \mathrm{hr}$ in phosphate-buffered medium was there any noticeable reduction in the subsequent development of these embryos to the blastocyst stage in

Table 2. Effect of incubation in phosphatebuffered medium on the subsequent development of two- and eight-cell mouse embryos to blastocysts in bicarbonate-buffered medium

\begin{tabular}{c|c|c}
\hline $\begin{array}{c}\text { Period in } \\
\text { phosphate-buffered } \\
\text { medium before } \\
\text { culture } \\
(\text { hr })\end{array}$ & \multicolumn{2}{|c}{$\begin{array}{c}\% \text { embryos developing into } \\
\text { blastocysts from: }\end{array}$} \\
\cline { 2 - 3 } & $\begin{array}{c}2 \text {-cell } \\
\text { embryos }\end{array}$ & $\begin{array}{c}8 \text {-cell } \\
\text { embryos } \dagger\end{array}$ \\
\hline 0 & $58 \pm 5$ & $77 \pm 3$ \\
2 & $54 \pm 4$ & $86 \pm 2$ \\
4 & $46 \pm 2$ & $79 \pm 5$ \\
6 & $49 \pm 2$ & $88 \pm 4$ \\
8 & $43 \pm 3$ & $84 \pm 3$ \\
10 & $43 \pm 3$ & $68 \pm 2$ \\
12 & $36 \pm 4$ & $59 \pm 2$ \\
\hline
\end{tabular}

\footnotetext{
Mean values \pm S.E. of the means are given.

* Total of 100 embryos/treatment (five replicates, twenty embryos/treatment).

$\dagger$ Total of eighty embryos/treatment (four replicates, twenty embryos/treatment).
}

Table 3. The production of carbon dioxide by mouse embryos during incubation for $3 \mathrm{hr}$ in phosphate- or bicarbonate-buffered medium containing $0.5 \mathrm{~mm}-\left[2-{ }^{14} \mathrm{C}\right]$ pyruvate after culture for $21 \mathrm{hr}$ in either phosphate- or bicarbonate-buffered medium

\begin{tabular}{l|c|c}
\hline \multirow{2}{*}{ Embryo development during culture } & \multicolumn{2}{|c}{ Buffering system } \\
\cline { 2 - 3 } & Phosphate & Bicarbonate \\
\hline 2-cell to 4-/8-cell & $3 \cdot 0 \pm 0 \cdot 1(69)$ & $2 \cdot 2 \pm 0 \cdot 3(81)$ \\
Morula/early blastocyst to late blastocyst & $6 \cdot 9 \pm 1 \cdot 8(67)$ & $5 \cdot 7 \pm 0 \cdot 3(93)$ \\
\hline
\end{tabular}

Mean values of three replicates in each observation $\pm S$.E. of the mean are given. Values are expressed as pmol/embryo/3 hr with percentage of embryos developing during culture given in parentheses.

Values for freshly collected eight-cell embryos and late blastocysts were $2 \cdot 9 \pm 0 \cdot 3$ and $9 \cdot 5 \pm 0 \cdot 7$, respectively.

bicarbonate-buffered medium (Table 2). When these embryos were observed $24 \mathrm{hr}$ after the start of the experiment, however, the number of morulae developing from eight-cell embryos which had been incubated for $10 \mathrm{hr}$ or longer in phosphate-buffered medium was only slightly less than the number developing after shorter periods in phosphate. 


\section{Metabolic investigations}

Two-cell, eight-cell and morula stages of development were cultured for 21 to $24 \mathrm{hr}$ in medium buffered with either $4 \mathrm{~mm}$-phosphate or $25 \mathrm{~mm}$-bicarbonate. At the end of the culture period, the embryos which had developed were collected and various aspects of their metabolism were assayed.

Production of carbon dioxide. The production of $\mathrm{CO}_{2}$ from $\left[2-{ }^{14} \mathrm{C}\right]$ pyruvate was measured in embryos after culture for $21 \mathrm{hr}$ from the two-cell and morula stage and in freshly collected eight-cell embryos and late blastocysts. The results are given in Table 3 . There was a two- to threefold difference in the production of $\mathrm{CO}_{2}$ between the two stages of development in both the cultured and freshly collected embryos. The amount of $\mathrm{CO}_{2}$ produced by the cultured embryos was not significantly altered by the buffering system in which the embryos were cultured at either stage of development. The cultured embryos produced less $\mathrm{CO}_{2}$ than the freshly collected embryos, particularly at the blastocyst stage of development.

Incorporation of substrate carbon from pyruvate and lactate. The incorporation of substrate carbon from pyruvate and lactate by embryos after culture for $24 \mathrm{hr}$ in either phosphate- or bicarbonate-buffered medium was measured and the results are given in Table 4 together with a summary of the analyses of variance of the data. The incorporation of carbon into all fractions of the embryos increased as the stage of development of the embryo increased. Most of the radioactivity which accumulated in the embryos over the 2-hr incubation period was found in the acid-soluble fraction of the embryos. None of the accumulated substrate carbon was found in the ethanol-precipitated acid-soluble fraction of the embryos at any of the stages of development. The RNA and DNA fractions each accounted for 1 to $2 \%$ of the total substrate carbon accumulated. In general, the proportion in the DNA fraction was less than that in the RNA fraction. Accumulation of substrate carbon in the protein fraction of the embryos was generally two- to fourfold greater than the amount in either the RNA or DNA fractions. Less than $0.5 \%$ of the total substrate carbon accumulated was found in the lipid fraction of the embryos.

In embryos which had been cultured in phosphate-buffered medium for $24 \mathrm{hr}$ before incubation in the radioactive substrates, the uptake of carbon into most fractions of the embryos was lower than that in embryos which had developed in the bicarbonate-buffered medium. There was a fourfold difference in the incorporation of carbon into the protein fraction and a twofold difference in incorporation into the RNA fraction between morulae developing from the eight-cell stage in the two buffers. At all other stages, the difference in the incorporation into these two fractions was less marked. With incorporation into the DNA fraction, there was a twofold difference between the embryos cultured in the two buffers in those developing from the two-cell stage as well as in those developing from the eight-cell stage.

Levels of ATP. The levels of ATP in mouse embryos cultured for $24 \mathrm{hr}$ in either phosphate- or bicarbonate-buffered medium are given in Table 5, together with the amounts of ATP in freshly collected embryos at comparable stages of development. In two- and eight-cell embryos cultured for $24 \mathrm{hr}$ in bicarbonate-buffered medium, the levels of ATP were only $75 \%$ of those in 

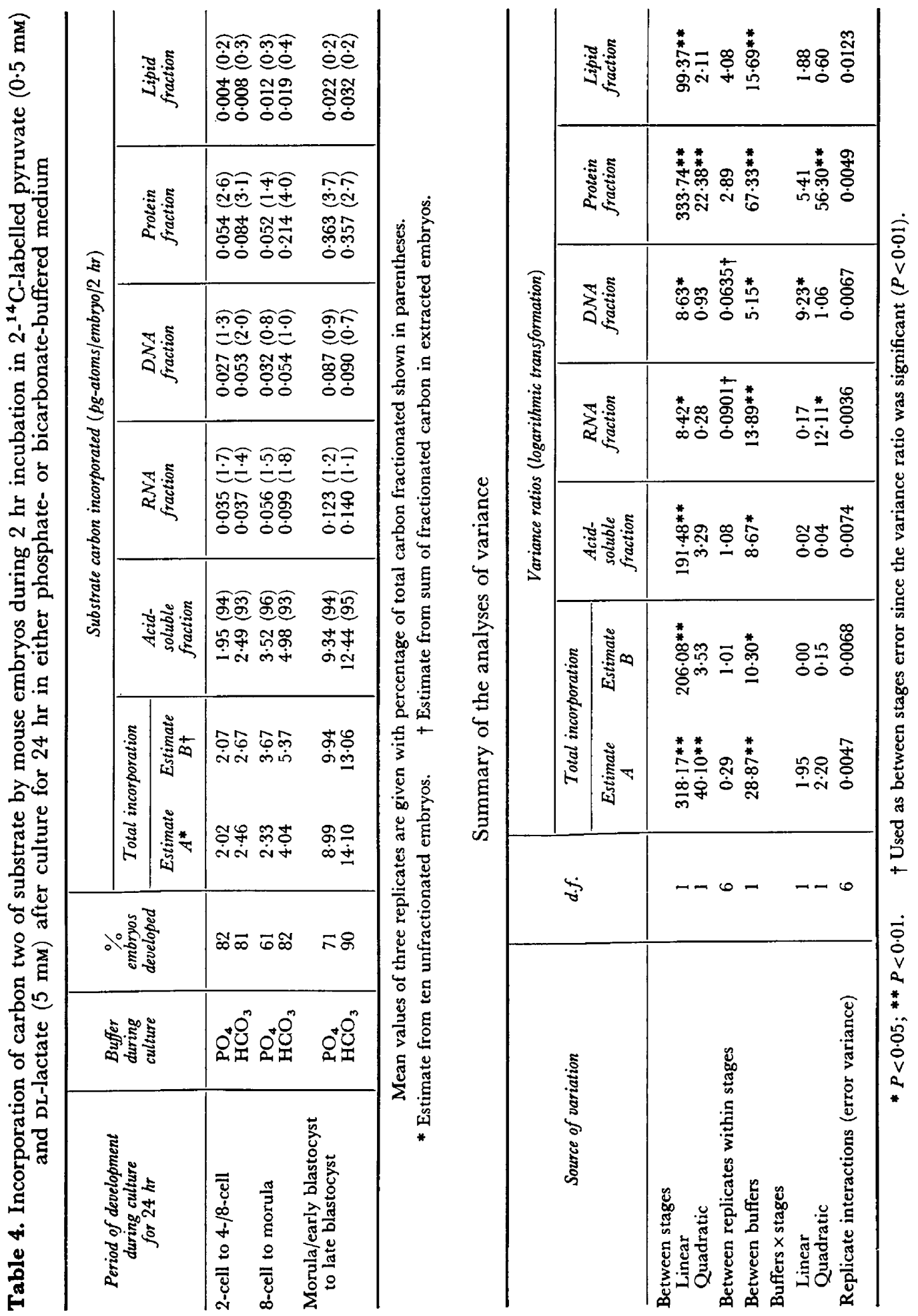
embryos cultured in the phosphate-buffered medium. In blastocysts cultured from the morula stage, however, there was no difference in the amounts of ATP in embryos cultured in either medium. Although the levels of ATP in the cultured embryos decreased as development progressed, they were still greater than the amounts found in freshly collected embryos at similar stages of development. The embryos cultured in bicarbonate-buffered medium had only 3 to $5 \%$ more ATP than the freshly collected embryos at the eight-cell and morula stages but, in cultured blastocysts, the amount of ATP in the embryos cultured in either phosphate- or bicarbonate-buffered medium was approximately $35 \%$ greater than that in freshly collected late blastocysts.

Table 5. Levels of ATP in mouse embryos after culture for $24 \mathrm{hr}$ in either phosphate- or bicarbonate-buffered medium

\begin{tabular}{l|c|c}
\hline \multirow{2}{*}{ Embryo development during culture } & \multicolumn{2}{|c}{ Buffering system } \\
\cline { 2 - 3 } & Phosphate & Bicarbonate \\
\hline 2-cell to 4-/8-cell & $0.93 \pm 0.04(96)$ & $0 \cdot 70 \pm 0.03(98)$ \\
8-cell to morula & $0 \cdot 85 \pm 0.07(62)$ & $0.63 \pm 0.01(93)$ \\
Morula/early blastocyst to late blastocyst & $0 \cdot 70 \pm 0.02(90)$ & $0.72 \pm 0.04(97)$ \\
\hline
\end{tabular}

Mean values of two replicates in each observation \pm S.E. of the mean are given. Values are expressed as pmol/embryo with percentage of embryos developing during culture given in parentheses.

Values for freshly collected eight-cell embryos, morulae and late blastocysts were $0 \cdot 67 \pm 0.02,0 \cdot 61 \pm 0.01$ and $0.53 \pm 0.05$, respectively.

Activity of $\mathcal{N} A D P$-malate dehydrogenase. The activity of NADP-malate dehydrogenase in embryos after culture for $24 \mathrm{hr}$ in medium buffered by either phosphate or bicarbonate was measured as previously described (Quinn \& Wales, 1971). No detectable differences in activity between embryos cultured in either medium or freshly collected embryos were observed.

\section{DISGUSSION}

The limited growth of mouse embryos in phosphate-buffered medium observed in the present experiments is similar to that found by Thomson (1969). In the present experiments, 4 mm-phosphate buffer in the medium supported the development of more two-cell mouse embryos than 1 mm-phosphate. With cultured eight-cell embryos and morulae, the two levels of phosphate were able to support development equally well over the $24-\mathrm{hr}$ culture period. In addition, the ability of more eight-cell than two-cell embryos to tolerate longer incubations in phosphate-buffered medium before their subsequent development in bicarbonate-buffered medium was substantially affected indicates that the mechanisms stabilizing the environment within the embryo become more developed as the age of the embryo increases.

The demonstration that the fixation of $\mathrm{CO}_{2}$ is an important process in the assimilation of energy substrates into the metabolic pools of mammalian embryos (Graves \& Biggers, 1970; Quinn \& Wales, 1971) might suggest that with non-bicarbonate buffers, additional substrates which are intermediates in 
the fixation of $\mathrm{CO}_{2}$ could prove beneficial to the growth of embryos. Gwatkin \& Siminovitch (1960) have shown that the addition of oxaloacetate to culture medium is beneficial to the maintenance of some tissues and cells cultured in non-bicarbonate medium but, in the present experiments, neither it nor malate enhanced embryonic development. Oxaloacetate or malate may not have stimulated the growth of mouse embryos because of the decarboxylation of these substrates to pyruvate by the embryos. Thus, in addition to depleting the intracellular pools of oxaloacetate and malate, this decarboxylation may increase the pyruvate concentration to a level which may not be optimal for development (see Brinster, 1965b). This could explain some of the deleterious effects of oxaloacetate or malate addition on development of embryos in the present experiments. Paul (1965) has utilized tris-citrate buffer to overcome the problem of oxaloacetate depletion in the absence of carbon dioxide and maintain the activity of the tricarboxylic acid cycle in cultured cells. A similar approach with mouse embryos could be worth while after the eight-cell stage. At the two-cell stage, however, very little citrate is incorporated into mouse embryos (Kramen \& Biggers, 1971) and its addition at this stage of development is unlikely to be beneficial. Nucleosides, which stimulate the development of cultured human cells in the absence of $\mathrm{CO}_{2}$ (Chang, Liepins \& Margolish, 1961), may also be found to promote the development of mouse embryos in phosphate-buffered medium.

The levels of ATP in two- and eight-cell embryos cultured in phosphate for $24 \mathrm{hr}$ were higher than those in embryos cultured in bicarbonate-buffered medium and this would suggest that there is either greater production or lower utilization of ATP by embryos cultured in medium buffered with phosphate. The oxidative turnover of pyruvate in cultured eight-cell embryos was unaffected by the buffer system used during culture and from this one can infer that differences in the production of ATP were small. Therefore, a decreased utilization of ATP in the embryos cultured in phosphate-buffered medium appears to be solely responsible for the high levels of ATP in these embryos. The marked decrease in the synthesis of all macromolecules in embryos cultured in phosphate-buffered medium up to the morula stage (Table 4), would result in a decreased utilization of ATP and could be responsible, in part at least, for the higher levels of ATP found in the embryos cultured in phosphate compared to the levels in embryos cultured in bicarbonate-buffered medium.

The utilization of ATP by blastocysts cultured in either phosphate- or bicarbonate-buffered medium would appear to be similar since ATP levels and oxidative utilization of substrates in these embryos are similar after culture in each medium. The utilization of ATP in cultured blastocysts must be considerably lower than that in freshly collected blastocysts since the levels of ATP were higher in cultured than in freshly collected blastocysts although the oxidation of pyruvate, and so presumably the production of ATP, was lower.

The inhibitory effect of phosphate-buffered medium on the development of mouse embryos was accompanied by a decreased incorporation of substrate carbon from pyruvate and lactate into the embryo at all stages of development. The absence of any detectable incorporation of carbon from pyruvate and lactate into the glycogen fraction of the embryos cultured in either phosphate- 
or bicarbonate-buffered medium is not surprising since phosphopyruvate carboxylase (E.C. 4.1.1.32), a key enzyme involved in gluconeogenesis from pyruvate, has not been found in mouse embryos (Quinn \& Wales, 1971). The synthesis of RNA, which increases markedly at the eight-cell stage (Mintz, 1964; Ellem \& Gwatkin, 1968; Piko, 1970), was more depressed in morulae which had been cultured from the eight-cell stage in phosphate-buffered medium than at the other stages of development. At this time, there was also a marked effect of buffering system on the incorporation of label into the protein fraction of the embryos. Some nucleic acid and protein synthesis is required for the development of mouse embryos (Thomson \& Biggers, 1966). In addition, Wales \& Whittingham (1973) have suggested that, in developing embryos, a stimulated incorporation of substrate carbon into the protein fraction of the early mouse embryo is beneficial to development and recent experiments (P. Quinn \& R. G. Wales, unpublished observations) have shown that more substrate carbon is incorporated into the protein fraction of two-cell mouse embryos which develop than in those which fail to cleave. Thus, an adequate synthesis of macromolecules from exogenous substrate appears to be a prerequisite for development of the mouse embryo and this does not occur when the embryos are cultured in phosphate-buffered medium.

\section{ACKNOWLEDGMENTS}

The authors are indebted to Professor C. W. Emmens for interest and criticism. The work was aided by a grant from the Australian Research Grants Committe. One of us (P.Q.) was supported by an Australian Wool Board Post-Graduate Studentship.

\section{REFERENCES}

Brinster, R. L. (1963) A method for in vitro cultivation of mouse ova from two-cell to blastocyst. Expl Cell Res. 32, 205.

Brinster, R. L. (1965a) Lactate dehydrogenase activity in the preimplanted mouse embryo. Biochim. biophys. Acta, 110, 439 .

Brinster, R. L. (1965b) Studies on the development of mouse embryos in vitro. II. The effect of energy source. 7. exp. Zool. 158, 59.

Brinster, R. L. (1967) Carbon dioxide production from glucose by the preimplantation mouse embryo. Expl Cell Res. 47, 271.

Ghang, R. L., Liepins, H. \& Margolish, M. (1961) Carbon dioxide requirement and nucleic acid metabolism of Hela and conjunctival cells. Proc. Soc. exp. Biol. Med. 106, 149.

Ellem, K. A. O. \& Gwatkin, R. B. L. (1968) Patterns of nucleic acid synthesis in the early mouse embryo. Devl Biol. 18, 311.

Graves, C. N. \& Biggers, J. D. (1970) Carbon dioxide fixation by mouse embryos prior to implantation. Science, N.Y. 167, 1506.

Gwatkin, R. B. L. \& Siminovitch, L. (1960) Multiplication of single mammalian cells in a nonbicarbonate medium. Proc. Soc. exp. Biol. Med. 103, 718.

Kramen, M. A. \& Biggers, J. D. (1971) Uptake of TCA cycle intermediates by preimplantation mouse embryos in vitro. Proc. natn. Acad. Sci. U.S.A. 68, 2656.

Mills, R. M. \& Brinster, R. L. (1967) Oxygen consumption of preimplantation mouse embryos. Expl Cell Res. 47, 337.

Mintz, B. (1964) Synthetic processes and early development in the mammalian egg. 7. exp. Zool. 157, 85.

Paul, J. (1965) Carbohydrate and energy metabolism. In: Cells and Tissues in Culture-Methods, Biology and Physiology, Vol. 1, p. 239. Ed. E. N. Willmer. Academic Press, London.

Piko, L. (1970) Synthesis of macromolecules in early mouse embryos cultured in vitro: RNA, DNA, and a polysaccharide component. Devl Biol. 21, 257. 
Quinn, P. \& Wales, R. G. (1971) Fixation of carbon dioxide by preimplantation mouse embryos in vitro and the activities of enzymes involved in the process. Aust. 7. biol. Sci. 24, 1277.

Quinn, P. \& Wales, R. G. (1973) The effect of culture in vitro on the levels of adenosine triphosphate in preimplantation mouse embryos. F. Reprod. Fert. 32, 231.

Shibko, S., Koivistoinen, P., Tratnyek, G. A., Newhall, A. R. \& Friedman, L. (1967) A method for sequential quantitative separation and determination of protein, RNA, DNA, lipid and glycogen from a single rat liver homogenate or from a subcellular fraction. Analyt. Biochem. 19, 514.

Thomson, J. L. (1969) Quoted by R. L. Brinster. In: The mammalian oviduct, p. 428. Eds. E. S. E. Hafez and R. J. Blandau. University of Chicago Press, Chicago.

Thomson, J. L. \& Biggers, J. D. (1966) The effect of inhibitors of protein synthesis on the development of mouse embryos in vitro. Expl Cell Res. 41, 411.

Umbreit, W. W., Burris, R. H. \& Stauffer, J. F. (1959) Manometric techniques and tissue metabolism. Burgess Publishing Co., Minneapolis.

Wales, R. G. \& Biggers, J. D. (1968) The permeability of two- and eight-cell mouse embryos to Lmalic acid. 7. Reprod. Fert. 15, 103.

Wales, R. G. \& Whittingham, D. G. (1967) A comparison of the uptake and utilization of lactate and pyruvate by one- and two-cell mouse embryos. Biochim. biophys. Acta, 148, 703.

Wales, R. G. \& Whittingham, D. G. (1970) Metabolism of specifically labelled pyruvate by mouse embryos during culture from the two-cell stage to the blastocyst. Aust. 7. biol. Sci. 26, 877.

Wales, R. G. \& Whittingham, D. G. (1973) The metabolism of specifically labelled lactate and pyruvate by two-cell mouse embryos. 7. Reprod. Fert. 33, 207.

Whitten, W. K. (1971) Nutrient requirements for the culture of preimplantation embryos in vitro. In: Advances in the Biosciences, Vol. 6, p. 129. Ed. G. Raspe. Pergamon Press, Oxford.

Whittingham, D. G. \& Wales, R. G. (1969) Storage of two-cell mouse embryos in vitro. Aust. J. biol. Sci. 22, 1065. 